\title{
The mating system in a Scots pine clonal seed orchard in Poland
}

\author{
J Burczyk \\ Polish Academy of Sciences, Institute of Dendrology, Department of Genetics, \\ 62 - 035 Kornik, Poland
}

(Received 13 November 1990; accepted 8 April 1991)

\begin{abstract}
Summary - The mating system of a clonal seed orchard of Pinus sylvestris $L$ consisting of 32 clones was studied using allozyme marker loci. Single-locus estimates of outcrossing rate ranged from $0.907-1.106$ (with a mean of 1.011), while the multilocus estimate was 0.987 . The outcrossing rates of individual trees ranged from $0.840-1.208$. The variance effective population size estimated for males was equivalent to 14 individuals. Some patterns of non-random mating were found. The level of inbreeding as measured by average fixation indices was low, both in the parental and the filial generations. The usefulness of Scots pine seed orchards in forest tree improvement has been discussed in the light of genetic efficiency.
\end{abstract}

Pinus sylvestris $\mathrm{L}$ / seed orchard / outcrossing / inbreeding / variance effective population size

Résumé - Système de croisements dans une pinède de clones de pins sylvestres, issus de graines, en Pologne. Le système de croisements dans une pinède de Pinus sylvestris composée de 32 clones est étudié grâce à des locus d'allozymes marqueurs. On estime, d'après le taux de croisements, les locus uniques à 0,907-1,106 (moyenne: 1,011) et les locus multiples à 0,987. Les taux de croisements d'arbres considérés individuellement sont de 0,840-1,208. On évalue la population de mâles utilisée pour la détermination de la variance à 14 individus. On trouve quelques modèles de croisement non aléatoire. Le niveau dínbreeding, mesuré par les index de fixation moyenne, est faible, aussi bien dans les générations parentales que dans les générations filles. L'utilité pour l'amélioration des arbres forestiers de pinèdes de pins sylvestres dont les individus sont issus de graines est discutée en termes d'efficacité génétique.

Pinus sylvestris $L$ / pinède à individus issus de graines / croisement / inbreeding / taille de la population servant au calcul de la variance 


\section{INTRODUCTION}

Seed orchards are established to promote the production of seeds of high genetic value. The clones used in such plantations are phenotypically or genetically selected from natural or artificial stands, and are replicated many times as grafts. It is assumed that full panmixis occurs within an orchard and that all clones make an equal contribution to the filial generation. However, many studies have demonstrated nonrandom mating in seed orchards of some conifers (Cheliak, 1984; Müller-Starck, 1984; Barrett et al, 1987) and thus the evaluation of genetic efficiency of seed orchards is of great practical importance in forest tree improvement. Many seed orchards established in Poland in the early 1970 s have reached the commercial cone crop production stage. Breeders are trying to design the next generation of seed orchards and more information is required to understand the processes of mating occurring in such artificial populations. To describe seed orchard efficiency, it is useful to study the levels of inbreeding and proportion of individuals effectively contributing to the filial generation.

Scots pine (Pinus sylvestris $L$ ) is the species with which most seed orchards have been established in Europe. The intensity of male and especially female flowering, and the relative stability of high cone crops from year to year result in Scots pine seed orchards still being regarded by foresters as valuable and useful sources of seeds. The mating system of Scots pine seed orchards has been studied in recent years (Rudin and Lindgren, 1977; Shen et al, 1981; Müller-Starck, 1982; Rudin and Ekberg, 1982; Rudin et al, 1986), and the estimates of outcrossing levels ranged from $0.84-0.98$. When efficient multilocus methods were used, the estimates ranged from 0.91-0.977 (Koski and Muona, 1986;
El-Kassaby et al, 1989; Muona and Harju, 1989). Information on seed orchard mating systems analyzed based on multilocus methods for other conifers is limited (Adams and Birkes, 1991). Mating systems of individual trees have also been studied using multilocus methods (Shaw and $\mathrm{Al}$ lard, 1982a; Neale and Adams, 1985; Ritland and El-Kassaby, 1985; Koski and Muona, 1986; Perry and Dancik, 1986; ElKassaby et al, 1987; Moran et al, 1989). The assumption of the estimation of population outcrossing rate is that the outcrossing rate is constant among individuals in the population. However, heterogeneity of outcrossing among trees has been observed in seed orchards (Shaw and Allard, 1982a) and natural populations (Neale and Adams, 1985). Apart from the theoretical value of such studies they are also of practical interest, especially when openpollinated seeds collected from individual trees are used for reforestration.

Many conifers, including Scots pine, exhibit strong inbreeding depression (Koski, 1973) and estimates of the mating system parameters are important for detecting non-random mating events that increase the levels of inbreeding. Knowledge about the rates of selfing would allow breeders to predict losses caused by inbreeding depression, following self-fertilization, when seeds from a particular seed orchard are used for reforestration.

\section{MATERIALS AND METHODS}

The Gniewkowo clonal seed orchard was established by the Torun Regional State Forest Administration in 1972 and is located $\approx 30 \mathrm{~km}$ south-west of Torun, Poland. The site was an agricultural field and the nearest Scots pine stands are located $1.5 \mathrm{~km}$ away towards the north-west. Scions were collected from 32 selected Scots pine, plus trees growing in 3 forest districts in the Tuchola forests. Grafts were out- 
planted at $5 \times 5 \mathrm{~m}$ spacing. The orchard was arranged in 3 blocks. Each block was 0.935 ha in size and contained all the clones randomly distributed in different proportions (see Burczyk, 1990 for details).

In January 1989 cones were collected from several branches of a single ramet of each of the 32 clones from 1 block. Extracted seeds (embryo and megagametophyte tissues) were analyzed using standard electrophoretic techniques (Yeh and O'Malley, 1980). Three enzyme systems were assayed by starch gel electrophoresis: aspartate amino-transferase (EC 2.6.1.1; AAT), glutamate dehydrogenase (EC 1.4.1.2; GDH), malate dehydrogenase (EC 1.1.1.37; $\mathrm{MDH}$ ), and 6 variable gene loci were recorded in both seed tissues (Aat-1, Aat-2, Aat-3, Gdh, Mdh-3, Mdh-4). For the MDH enzyme loci the notation presented by Müller-Starck (1984) was used. The extraction and staining buffers were according to Yeh and O'Malley (1980) with slight modifications.

\section{Data analysis}

Twenty seeds were analyzed electrophoretically for each of the 32 clones. An additional 40 seeds were analyzed for each of 16 clones chosen based on the probability of detecting outcross pollen gametes (see below); thus the mating system of individual trees was studied based on 60 seeds. The numbers of seeds for population and individual tree mating system parameters were constant per clone to arrive at a proper mean estimate. The single-locus $\left(t_{s}\right)$ and multilocus $\left(t_{m}\right)$ levels of outcrossing for the population, and the multilocus outcrossing rate for individual trees $\left(t_{m i}\right)$ were estimated based on a mixed mating model using the maximum likelihood procedures and programs described by Neale and Adams (1985). The clones for estimation of individual tree outcrossing rates were chosen based on the conditional probability of detecting outcross pollen gametes calculated for each parental genotype after single-locus estimation (Neale and Adams, 1985). When this probability is relatively small a great number of seeds needs to be analyzed. The planned size of an analyzed progeny for outcrossing estimation of individual trees was not very large, and thus only those 16 clones were chosen for which the conditional probabilities were the highest ( $>0.7$ ). This could be made based on an as- sumption of a mixed mating model, where the probability of an outcross is independent of genotype of the maternal plant (Shaw et al, 1981). Allele frequencies in the outcross pollen pool were estimated based on 20 seeds.

Spatial homogeneity of allele frequencies in the pollen pool was studied across homozygous trees by way of a $\chi^{2}$ analysis (Brown et al, 1975). Homogeneity of maternal and paternal genetic contribution into the gene pool was evaluated by means of a $\chi^{2}$ test, the frequency counts obtained from the progeny being the observed values of ovule and pollen alleles (Barrett et al, 1987).

The variance effective population size was estimated based on allele frequencies estimated in the mature and filial generations. The method proposed by Yasuda was used (Yasuda, 1969; after Cheliak et al, 1985). The actual breeding size is reduced to a value equivalent to the number of individuals in the idealized theoretical population, exhibiting the same increase in homozygosity as in the observed population (Crow and Kimura, 1970). In conifers it is possible to estimate separately the allele frequencies in maternal and paternal gametes contributed to the next generation; thus the effective number of females and males can be obtained. However, in the studied case the effective number of females could not be estimated, because equal number of seeds per female was analyzed, and only male gametes could be considered as a random sample.

The frequencies of genotypes observed in mature and the filial generation were compared to that expected under panmixis (HardyWeinberg equilibrium) based on a G-test (Sokal and Rohlf, 1973). The extent of inbreeding was estimated by means of Wright's fixation index, using the formula: $F=1-H_{\alpha} / H_{e}$, where $H_{o}$ is observed heterozygosity and $H_{e}$ is expected heterozygosity according to Nei (1975). The variances of the $F$ indices were obtained by the method of Brown (1970).

When self-fertilization is the sole factor affecting level of inbreeding an expected equilibrium coefficient can be calculated: $F_{e}=\left(1-t_{m}\right) /(1+$ $\left.t_{m}\right)$, where $t_{m}$ is the multilocus outcrossing rate (Allard et al, 1968). A substantial difference between $F$ and $F_{e}$ indicates that inbreeding other than through selfing occurs in the population (Shaw and Allard, 1982b). All tests of heterogeneity were made using $\chi^{2}$ according to Rao (1973). 


\section{RESULTS}

Single-locus $\left(t_{s}\right)$ estimates of outcrossing rate ranged from 0.907 for the locus $M d h-3$ to 1.106 for the Gdh locus, with an average of 1.011, and were not significantly heterogeneous over the studied loci (table I). The multilocus $\left(t_{m}\right)$ estimate of outcrossing was 0.987 and was lower than the average of single locus estimates. Multilocus estimates of outcrossing rate for individual trees $\left(t_{m i}\right)$ ranged from 0.840 for clone No 214 to 1.208 for clone No 232 and were not significantly heterogeneous across the studied clones (table II). The average was calculated to be 1.017 and was higher than the multilocus outcrossing rate estimated for the population.

Analysis of the variance effective population size indicated that the actual breeding size of males is equivalent to 14 individuals contributing gametes to the next generation. When the maternal genetic contribution into the gene pool was compared with the paternal one significant differences were observed for loci Aat-2 $\left(\chi^{2}=6.00, P<0.05\right)$ and $\operatorname{Gdh}\left(\chi^{2}=14.04\right.$, $P<0.001)$. Allele frequencies in the pollen pool were spatially homogeneous across the sampled trees for all polymorphic loci.

Excess of heterozygosity was observed in the parental population and the average Wright's fixation index was calculated to be -0.199 (table III). This excess was statistically significant for Aat-2 and Gdh. In the filial population significant excess of heterozygotes was detected for Gdh and Mdh-4, but a significant deficiency of heterozygotes was observed for the Aat-3 locus (table (II).

\section{DISCUSSION}

The investigations indicated a high proportion of outcrossing in the seed orchard examined. Previous studies in Scots pine seed orchards showed that the outcrossing rate varied widely $(0.84-0.988$; see table IV). However, most of them were made on individual clones using the unique markeralleles method: thus they cannot be considered population estimates. Results on the mating system calculated by the more efficient single-locus or multilocus methods have only been reported by Koski and $\mathrm{Mu}$ -

Table I. Single- $\left(t_{s}\right)$ and multilocus $\left(t_{m}\right)$ estimates of outcrossing rate, and allele frequencies of outcrossed pollen pool in the Gniewkowo clonal seed orchard (standard error in parentheses).

\begin{tabular}{|c|c|c|c|c|}
\hline \multirow{2}{*}{ Locus } & \multirow{2}{*}{$t_{s}$} & \multicolumn{3}{|c|}{ Allele frequency } \\
\hline & & $A 1$ & $A 2$ & $A 3$ \\
\hline Ast-1 & $1.048(0.012)$ & $0.023(0.006)$ & $0.977(0.006)$ & - \\
\hline Aat-2 & $1.012(0.049)$ & $0.055(0.009)$ & $0.409(0.019)$ & $0.536(0.023)$ \\
\hline Aat-3 & $0.920(0.068)$ & $0.338(0.021)$ & $0.662(0.021)$ & - \\
\hline$G d h$ & $1.106(0.074)$ & $0.316(0.017)$ & $0.684(0.017)$ & - \\
\hline$M d h-3$ & $0.907(0.053)$ & $0.748(0.019)$ & $0.252(0.019)$ & - \\
\hline$M d h-4$ & $1.074(0.037)$ & $0.066(0.009)$ & $0.395(0.018)$ & $0.539(0.022)$ \\
\hline \multicolumn{5}{|c|}{$\begin{array}{l}t_{s}=1.011 \\
t_{m}=0.987(0.02)\end{array}$} \\
\hline
\end{tabular}


Table II. Individual tree multilocus estimates of outcrossing rate (standard error in parentheses).

\begin{tabular}{lc}
\hline Clone No & $t_{m i}$ \\
\hline 210 & $1.141(0.065)$ \\
211 & $0.910(0.088)$ \\
213 & $0.912(0.083)$ \\
214 & $0.840(0.090)$ \\
215 & $1.007(0.030)$ \\
218 & $1.118(0.010)$ \\
220 & $0.995(0.044)$ \\
222 & $1.027(0.045)$ \\
223 & $1.005(0.029)$ \\
225 & $1.006(0.077)$ \\
227 & $0.939(0.041)$ \\
229 & $1.143(0.037)$ \\
231 & $1.007(0.078)$ \\
232 & $1.208(0.057)$ \\
236 & $0.905(0.049)$ \\
238 & $1.124(0.036)$ \\
&
\end{tabular}

ona (1986) El-Kassaby et al (1989) and Muona and Harju (1989).

The presented multilocus estimate of outcrossing ( $\left.t_{m}=0.987\right)$ is very close to the multilocus estimates reported for 2 Finnish seed orchards of Scots pine (Muona and Harju, 1989). But the average of single-locus estimate is greater $\left(t_{s}=1.011\right)$ than other previously reported analogous estimates (table IV).

Comparison of single-locus and multilocus population estimates allows inference about the amount of inbreeding other than through selfing in populations (Shaw and Allard, 1982a). The mixed mating model assumes that if matings occur among genetically related trees, single-locus estimates are biased downward. This has often been observed for natural populations (Neale and Adams, 1985; El-Kassaby et al, 1987; Muona and Harju, 1989) and has been explained mainly by the family structure of a stand. In this study the mean of single-locus estimates is greater than the

Table III. G-test for Hardy-Weinberg equilibrium, expected heterozygosity (He) and Wright's Fvalues for particular loci, for maternal and progeny populations.

\begin{tabular}{|c|c|c|c|c|c|c|c|}
\hline & Aat-1 & Aat-2 & $\begin{array}{l}\text { Locus } \\
\text { Aat-3 }\end{array}$ & $G d h$ & $M d h-3$ & $M d h-4$ & Mean \\
\hline \multicolumn{8}{|l|}{ Maternal } \\
\hline $\mathrm{He}$ & 0.031 & 0.525 & 0.417 & 0.375 & 0.390 & 0.544 & 0.380 \\
\hline$F$ & -0.016 & -0.487 & -0.273 & -0.333 & 0.119 & -0.205 & -0.199 \\
\hline$S E(F)$ & $(0.017)$ & $(0.430)$ & $(0.138)$ & $(0.079)$ & $(0.185)$ & $(0.173)$ & \\
\hline$G$ & 0.016 & 9.804 & 2.698 & 5.437 & 0.436 & 6.262 & \\
\hline$d f$ & 1 & 3 & 1 & 1 & 1 & 3 & \\
\hline$P$ & NS & $<0.05$ & NS & $<0.05$ & NS & NS & \\
\hline \multicolumn{8}{|l|}{ Progeny } \\
\hline $\mathrm{He}$ & 0.041 & 0.532 & 0.443 & 0.400 & 0.383 & 0.551 & 0.392 \\
\hline$F$ & -0.022 & 0.002 & 0.078 & -0.109 & 0.067 & -0.098 & -0.014 \\
\hline$S E(F)$ & $(0.010)$ & $(0.040)$ & $(0.040)$ & $(0.036)$ & $(0.041)$ & $(0.017)$ & \\
\hline$G$ & 0.582 & 4.629 & 3.892 & 7.944 & 2.792 & 9.591 & \\
\hline df & 1 & 3 & 1 & 1 & 1 & 3 & \\
\hline$P$ & NS & NS & $<0.05$ & $<0.01$ & NS & $<0.05$ & \\
\hline
\end{tabular}

NS = not significant at the $P<0.05$ level. 
Table IV. Comparison of mating system estimates observed in Scots pine seed orchards.

\begin{tabular}{|c|c|c|}
\hline t-Value & $\begin{array}{c}\text { Examined } \\
\text { material } \\
\text { (No clones) }\end{array}$ & Authors \\
\hline \multicolumn{3}{|c|}{ Unique marker alleles method } \\
\hline $0.95-0.98$ & - & Rudin and Lindgren, 1977 \\
\hline 0.94 & 1 & Shen et al, 1981 \\
\hline $0.84^{a}$ & 5 & Rudin and Ekberg, 1982 \\
\hline $0.86-0.88^{b}$ & 1 & Muller-Starck, 1982 \\
\hline $0.92^{\mathrm{a}}$ & 5 & Rudin et al, 1986 \\
\hline \multicolumn{3}{|c|}{ Single locus method } \\
\hline 0.940 & 25 & Muona and Harju, 1989 \\
\hline 0.988 & 28 & Muona and Harju, 1989 \\
\hline 0.934 & 39 & El-Kassaby et al, 1989 \\
\hline 0.929 & 58 & El-Kassaby et al, 1989 \\
\hline 1.011 & 32 & Present study \\
\hline \multicolumn{3}{|c|}{ Multilocus method } \\
\hline 0.910 & 25 & Koski and Muona, 1986 \\
\hline 0.976 & 25 & Muona and Harju, 1989 \\
\hline 0.978 & 28 & Muona and Harju, 1989 \\
\hline 0.957 & 39 & El-Kassaby et al, 1989 \\
\hline 0.961 & 58 & El-Kassaby et al, 1989 \\
\hline 0.987 & 32 & Present study \\
\hline \multicolumn{3}{|c|}{ Individual tree multilocus method } \\
\hline $0.91-0.97$ & 7 & Koski and Muona, 1986 \\
\hline $1.017^{\mathrm{a}}$ & 16 & Present study \\
\hline
\end{tabular}

a Unweighted mean over clones; ${ }^{b}$ range for 3 seasons.

multilocus one. Seed orchards are artificial populations created by foresters and because of permutated neighborhood distribution of grafted clones within a plantation they are expected to be free of the family structure or isolated mating groups, except for plantations arranged according to a systematic layout (Giertych, 1971). Thus the single-locus estimates of a seed orchard reflect selfing only, without any other form of inbreeding (Barrett et al, 1987).

Individual tree multilocus estimates $\left(t_{m i}\right)$ could be compared to values obtained by the unique marker alleles method, because both methods evaluate the outcrossing level for individual clones. When the unique marker alleles method is used, $t$-values never exceed unity and only the lower-bound estimates of $t_{m i}$ can be compared. The lowest reported values of outcrossing obtained by the unique marker alleles method and presented in this study are very similar. Individual tree outcrossing rates obtained in this study fell within the range of variation of the individual outcrossing rates based on the multilocus method reported by Koski and Muona (1986) (table IV), confirming low variation of outcrossing among clones.

It is interesting that the averages of individual tree outcrossing rates are very often greater than the multilocus estimates for a 
population (Neale and Adams, 1985; Ritland and El-Kassaby, 1985; El-Kassaby et al, 1987; and the present study), which is usually due to the influence of some trees with an outcrossing rate estimate exceeding unity. For multilocus estimates values of outcrossing greater than one are possible if the proportion of detectable outcrosses in the progeny sample is greater than that expected on the basis of detection probability for an individual tree (Neale and Adams, 1985). This biologically unrealistic value observed for different loci (table I) or individual trees (table II), could be due to negative assortative mating or could just be due to sampling error (Brown et al, 1984), especially when $t$ is near 1 and sample sizes are small (Adams and Birkes, 1991). The negative assortative mating occurs when individuals of particular genotypes mate with each other less frequently than expected under panmixis, and it could be an effect of phenological differences in male and female flowering within and among trees (Sarvas, 1962). This could probably be more clearly manifested for single trees than for a whole population. Each individual tree in a stand is surrounded by the trees of different genotypes. When differences in flowering among them exist, which is common for most conifers including Scots pine (Jonsson et al, 1976), pollen from only a few clones is effective in the fertilization process, influencing the system of mating of individual trees. The average of individual tree estimates are in fact female estimates of outcrossing rate (Ritland and ElKassaby, 1985) and could often differ from the population outcrossing average, which is identical for males and females (Ross and Gregorius, 1983). Variation among trees in self-ferility may complicate analysis of data from wind pollinated progeny tests. Progeny of trees with low outcrossing rates may cause overestimation of additive genetic variance and potential genetic gains (Perry and Dancik, 1986). The genetic reasons of self-fertility variation are quite complicated and cannot be fully explained.

Variance effective population size estimated for males showed that it is equivalent to 14 individuals in an ideal theoretical population, all with an equal opportunity to mate. Fourteen effective males represent $44 \%$ of the actual number of males. The imbreeding effective population size for 2 Finnish orchards of Scots pine was estimated to be $66 \%$ and $93 \%$ of the actual number of clones (Muona and Harju, 1989). The effective population size of $z y$ gotes derived from seed orchards is probably most affected by asynchronous phenology and asymmetrical male and female fertility (Cheliak, 1984; Müller-Starck, 1984). For a Douglas fir seed orchard it was shown that estimates of outcrossing for a group of clones with an intermediate reproductive phenology were the highest, indicating maximum panmixis during the height of flowering (El-Kassaby et al, 1988). However, flowering was not investigated in this study.

The level of inbreeding as measured by average fixation indices was low in the parental and filial generations. Lack of inbreeding in the progeny is in line with the negative assortative mating events detected in some cases. The observed genotypic distribution, compared to that expected under Hard-Weinberg equilibrium showed a significant excess of heterozygotes in both generations for some loci. Since the clones are phenotypically selected genotypes, departure from Hardy-Weinberg equilibrium is not unexpected for the mature trees. When the whole seed orchard was considered as a population consisting of 1056 grafts, the departure was very significant for all loci except Aat-1 (Burczyk, 1990; in press). However, random mating would bring loci back into equilibrium in the filial generation. The excess of heterozygotes in the 
progeny and the differences between maternal and paternal contribution into the gene pool are evidence of some type of non-random mating patterns or of selective mortality of homozygous embryos.

Similarity between $F$ and $F_{e}$ and lack of mating among relatives suggest that selffertilization is the main factor affecting inbreeding in the studied population. Equilibrium populations exhibit a relationship between Wright's fixation index $(F)$ and outcrossing rate $(t)$ according to formula $F=$ $(1-t) /(1+t)$ (Allard et al, 1968), thus $t=$ $(1-F) /(1+F)$. Observed fixation index of -0.014 (table IiI) in the progeny suggests an outcrossing rate of 1028 , which is very close to the mean of single-locus estimates $\left(t_{s}=1.011\right.$ ) (table I). Thus singlelocus outcrossing estimates of seed orchards reflect selfing only without any other form of inbreeding (Barrett et al, 1987).

The high out-crossing rate, homogeneity of the pollen pool, and relatively great number of males and females effectively contributing gametes to the next generation are positive characteristics of the analyzed population, but the observed patterns of non-random mating are not. Background pollination from pollen parents outside of the orchard was not investigated in this orchard and it may increase the rate of outcrossing of a seed orchard. The presented results and some other studies (Rudin et al, 1986; Muona and Harju, 1989) allow the conclusion that Scots pine seed orchards can be regarded as a source of genetically valuable seeds; thus establishment of further generations of seed orchards is needed, and seems promising for this species.

\section{ACKNOWLEDGMENTS}

This research was supported by Grants from the Polish Forest Research Institute and the Polish Academy of Sciences. The author tanks
WT Adams for the computer programs used in mating system estimation and $A$ Lewandowski for his help in developing the electrophoretic techniques. The technical assistance of A Piekuta and $H$ Przybyl is greatly appreciated.

\section{REFERENCES}

Adams WT, Birkes DS (1991) Estimating mating patterns in forest tree populations. In: Proc Int Workshop on Plant Biology. Biochemical Markers in the Population Genetics of Forest Trees. Inst Agrofor, Nat Res Council Italy (CNR), Porano-Orvieto, Italy, Oct 11-13, 1988 (in press)

Allard RW, Jain SK, Workman PL (1968) The genetics of inbreeding populations. Adv Genet $14,55-131$

Barrett JW, Knowles P, Cheliak WM (1987) The mating system in a black spruce clonal seed orchard. Can J For Res 17, 379-382

Brown AHD (1970) The estimation of Wright's fixation index from genotypic frequencies. Genetica 41, 399-406

Brown AHD, Matheson AC, Eldridge KG (1975) Estimation of the mating system of Eucalyptus obliqua L'Herit by using allozyme polymorphisms. Aust J Bot 23, 931-949

Brown AHD, Barrett SCH, Moran GF (1985) Mating system estimation in forest trees: models, methods and meanings. In: Population Genetics in Forestry (Gregorius HR, ed) Springer-Verlag, Berlin, 32-49

Burczyk J (1990) Struktura genetyczna plantacji nasiennej sosny zwyczajnej (Pinus sylvestris L). Arbor Kórnickie 35 (in press)

Cheliak WM (1984) Mating system dynamics in a Scots pine seed orchard. In: Proc IUFRO Working Party on Ecological Population Genetics. Göttingen, 1984, 107-117

Cheliak WM, Pitel JA, Murray G (1985) Population structure and mating system of white spruce. Can J For Res 15, 301-308

Crow JF, Kimura M (1970) An introduction to Population Genetics Theory. Harper and Row, NY

El-Kassaby YA, Meagher MD, Parkinson J, Portlock FT (1987) Allozyme inheritance, heterozygosity and outcrossing rate among Pinus 
monticola near Ladysmith, British Columbia. Heredity 58, 173-181

El-Kassaby YA, Ritland K, Fashler AMK, Devitt WJB (1988) The role of reproductive phenology upon the mating system of a Douglas-fir seed orchard. Silvae Genet 37, 76-82

El-Kassaby YA, Rudin D, Yazdani R (1989) Levels of outcrossing and contamination in two Pinus sylvestris $L$ seed orchards in Northern Sweden. Scand J For Res 4, 41-49

Giertych M (1971) Systematic lay-outs for seed orchards. Silvae Genet 20, 137-138

Jonsson A, Ekberg I, Eriksson G (1976) Flowering in a seed orchard of Pinus sylvestris $\mathrm{L}$. Stud For Suec 135, 1-38

Koski V (1973) On self-pollination, genetic load, and subsequent inbreeding in some conifers. Commun Inst For Fenn 78.10, 1-42

Koski V, Muona O (1986) Probability of inbreeding in relation to clonal differences in male flowering and embryonic lethals. Proc IUFRO Meeting of Working Groups on Breeding Theory Progeny Testing and Seed Orchards. Virginia USA, 391-400

Moran GF, Bell JC, Griffin AR (1989) Reduction in levels of inbreeding in a seed orchard of Eucalyptus regnans $\mathrm{F}$. Muell compared with natural populations. Silvae Genet 38, 32-36

Muona O, Harju A (1989) Effective population sizes, mating system and genetic variability in Scots pine natural populations and seed orchards. Silvae Genet 38, 221-228

Müller-Starck G (1982) Reproductive systems in conifer seed orchards. I. Mating probabilities in a seed orchard of Pinus sylvestris L. Silvae Genet 31, 188-197

Müller-Starck G (1984) Reproductive success of genotypes of Pinus sylvestris $L$ in different environments. In: Population Genetics in Forestry (Gregorius HR, ed) Springer-Veriag, Berlin, 118-133

Neale DB, Adams WT (1985) The mating system in natural and shelterwood stands of Douglas fir. Theor App/ Genet 71, 201-207

Nei M (1975) Molecular Population Genetics and Evolution. North-Holland Publ Co, Amsterdam

Perry DJ, Dancik BP (1986) Mating system dynamics of lodgepople pine in Alberta, Canada. Silvae Genet 35, 190-195
Rao CR (1973) Linear Statistical inference and its Applications. John Wiley and Sons, NY, 2nd edn

Ritland K, El-Kassaby Y (1985) The nature of inbreeding in a seed orchard of Douglas fir as shown by an efficient multilocus model. Theor Appl Genet 71, 375-384

Ross MD, Gregorius HR (1983) Outcrossing and sex function in hermaphrodites: a resource-allocation model. Am Nat 121, 204222

Rudin D, Lindgren D (1977) Isozyme studies in seed orchards. Stud For Suec 139, 1-23

Rudin D, Ekberg I (1982) Genetic structure of open-pollinated progenies from a seed orchard of Pinus sylvestris. Silva Fenn 16, 8793

Rudin D, Muona O, Yazdani R (1986) Comparison of the mating system of Pinus sylvestris in natural stands and seed orchards. Hereditas 104, 15-19

Sarvas $R$ (1962) Investigations on the flowering and seed crop of Pinus sylvestris. Commun Inst For Fenn 53.3, 1-198

Shaw DV, Allard RW (1982a) Estimation of outcrossing rates in Douglas fir using isozyme markers. Theor App/ Genet 62, 113-120

Shaw DV, Allard RW (1982b) Isozyme heterozygosity in adult and open-pollinated embryo samples of Douglas fir. Silva Fenn 16, 115121

Shaw DV, Kahler AL, Allard RW (1981) A multilocus estimator of mating system parameters in plant populations. Proc Natl Acad Sci USA 78, 1298-1302

Shen $\mathrm{HH}$, Rudin D, Lindgren D (1981) Study of the pollination pattern in a Scots pine seed orchard by means of isozyme analysis. Silvae Genet 30, 7-15

Sokal RR, Rohlf RF (1973) An Introduction to Biostatistics. Freeman, San Francisco, CA

Yasuda $N$ (1969) The estimation of the variance effective population number based on gene frequency. Jpn J Hum Genet 14, 10-15

Yeh FC, O'Malley DM (1980) Enzyme variation in natural populations of Douglas fir (Pseudotsuga menziesii (Mirb) Franco) from British Columbia. I. Genetic variation patterns in coastal populations. Silvae Genet 29, 83-92 